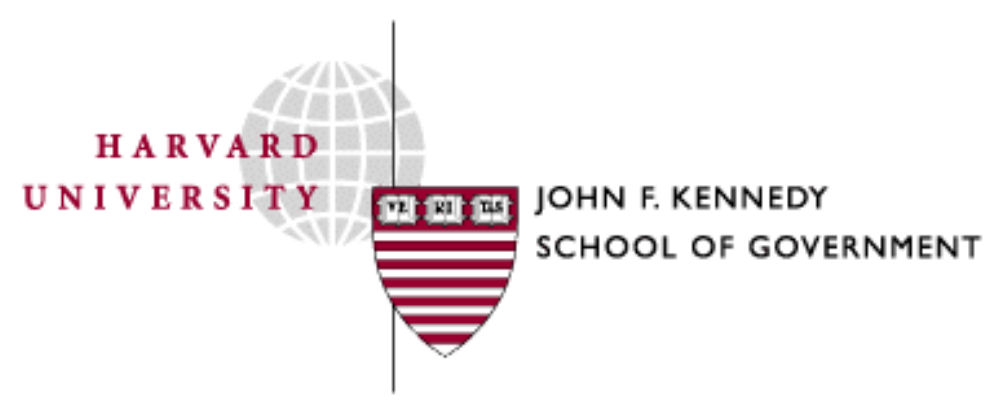

Faculty Research Working Papers Series

\title{
Will Bank Bailouts Bust Budgets? Fiscalization of the East Asian Financial Crisis Jay Rosengard
}

March 2004

RWP04-012 belongs to the author(s). Papers may be downloaded for personal use only. 


\title{
Will Bank Bailouts Bust Budgets? Fiscalization of the East Asian Financial Crisis
}

\author{
Jay K. Rosengard*
}

East Asia has returned to a position of relative financial stability and modest economic growth seven years since the onset of the East Asian financial crisis, but the long-range impact of the crisis is still unclear, especially regarding potential fiscal ramifications. The pre-crisis and post-crisis fiscal policies and performances of Thailand and Indonesia are examined to assess whether fiscalization of the financial crisis will in turn lead to a fiscal crisis. Thailand and Indonesia were two of the hardest hit economies during the crisis, and each had exemplary fiscal policies before the crisis. Since the crisis, both countries have maintained prudent fiscal policies, keeping budget deficits relatively small, managing debt burdens effectively, and limiting exposure to contingent liabilities. Both Thailand and Indonesia have addressed the short-term triggers of the financial crisis admirably, and continue to monitor vigilantly their external vulnerabilities. Thus, if either country now experiences a fiscal crisis, it will be the result of other factors bank bailouts will bust budgets only if banks have to be bailed out once again due to incomplete or insufficient financial sector reform.

\section{Introduction $^{1}$}

It has been almost seven years since the onset of the East Asian financial crisis. The region has returned to a position of relative financial stability and modest economic growth. In general, banks are liquid and solvent, inflation is low, exchange rates are less volatile, and economic activity is increasing. However, the long-range impact of the financial crisis is still unclear, especially in terms of fiscal ramifications.

The bank bailouts were financed mainly through off-budget mechanisms such as the issuance of recapitalization bonds, which now comprise a substantial portion of total public sector debt and entail significant direct on-budget costs as this debt is serviced. Blanket guarantees of depositors and financial institution creditors have created large contingent liabilities. In some countries, the fundamental financial sector structural weaknesses were not addressed as the urgency of crisis was replaced by the complacency of calm, so non-performing loans are growing on the balance sheets of banks and future bailouts might be necessary. This problem is compounded by low levels of lending for other than consumer finance, largely as a result of weak effective demand for credit, increased risk aversion of creditors, and crowding out of the private sector credit by public sector issuance of securities to finance budget deficits.

\footnotetext{
*Director, Financial Sector Program and Lecturer in Public Policy, Center for Business and Government, John F. Kennedy School of Government, Harvard University.

${ }^{1}$ I would like to thank Aswin Techajareonvikul for his excellent research assistance in the preparation of this paper.
} 
The economic recoveries have also been consumption rather than production led, in some cases supported by government stimulus packages, the combination of which could result in further financial sector stress due to consumer overcrediting and unsustainable household debt levels, as well as greater fiscal stress because of lower tax revenue and unsustainable public sector expenditure levels.

This paper will examine whether fiscalization of the recent financial crisis will in turn lead to a future fiscal crisis by evaluating pre-crisis and post-crisis fiscal policies and performances of Thailand and Indonesia. Fiscalization is seen in broad terms, comprising both the financing of bank bailouts and restructuring, as well as other public sector expenditures to mitigate the impact of the financial crisis and "kick start" the economy.

Thailand and Indonesia have been selected because they were two of the hardest hit countries during the crisis. While they are significantly different from both each other and their neighbors, the following analysis nonetheless provides a framework for analysis that can be useful to other countries when placed in local context, especially regarding severity of crisis impact and post-crisis macroeconomic performance.

\section{Pre-Crisis Fiscal Policies}

\section{Thailand}

Thailand's macroeconomic management prior to July 1997 was considered a model for other countries seeking sustainable development. Thailand had achieved substantial levels of economic growth over an extended period, and was the world's fastest growing economy in the decade ending in 1996 (Warr 1999). Thailand scored well on all conventional macroeconomic criteria, and its policies were consistently endorsed with great enthusiasm by multilateral institutions such as the World Bank, the Asian Development Bank (ADB), and the International Monetary Fund (IMF). ${ }^{2}$

Thailand's pre-crisis fiscal policies were no exception. Fiscal management was considered quite prudent, as indicated by the following examples: ${ }^{3}$

- $\quad$ Thailand consistently ran a budget surplus prior to the crisis, equaling 3.2 percent of GDP in 1995 and 0.7 percent of GDP in 1996.

- Total revenue to GDP in 1996 was a relatively healthy 18.5 percent.

- The composition of tax revenue in 1996 was diverse and reflected Thailand's level of economic development, as almost half of tax revenue (46 percent) was generated by taxes on consumption, with a bit more than a third (36 percent)

\footnotetext{
${ }^{2}$ See Rosengard 2002 for a detailed description of Thailand's pre-crisis macroeconomic performance.

${ }^{3}$ All of the budget figures in this section have been provided by Thailand's Comptroller-General and the Bank of Thailand (BOT), and refer to only central government revenues and expenditures.
} 
coming from taxes on income and profits, and most of the balance (16 percent) comprising taxes on international trade.

- Government expenditure as a share of the economy had been growing while maintaining a budget surplus, reaching 17.8 percent of GDP in 1996.

- The composition of government expenditure was conventional, with 61 percent for current expenditures (30 percent for wages and salaries and 22 percent for goods and services) and 39 percent for capital expenditures (31 percent for acquisition of fixed capital assets and 7 percent for capital transfers) in 1996 only 1 percent of expenditures were for interest payments in 1996.

In short, there was nothing exceptional or alarming in Thailand's conduct of its fiscal policy prior to the financial crisis, and the crisis clearly was not caused by public sector profligacy as was the case earlier in Latin America. Fiscal policies were prudent in Thailand, and Thailand's short- to medium-term fiscal position prior to the crisis was quite sound.

The only potential major threats to fiscal stability in Thailand were long-term. The most important of these were relatively weak tax administration, as indicated by widespread non-compliance of potential taxpayers, together with lack of a consolidated budget that reflected the unfunded pension programs whose burden would increase dramatically as Thailand's population aged.

\section{Indonesia}

Indonesia also had a reputation for sound macroeconomic management. Its economy was characterized by rapid economic development and diversification, with an average annual real GNP per capita growth rate of approximately 6 percent from 1985 to 1995.

Immediately prior to the crisis, GDP growth remained strong, increasing 8.2 percent in 1995 and 8.0 percent in $1996 .^{4}$

Indonesia's fiscal policies exemplified this overall prudent macroeconomic management, and included several rather unusual features. The most important of these was the concept of a "dynamic balanced budget," whereby all current ("routine”) expenditures and a portion of capital ("investment") expenditures were financed by tax and non-tax revenue, and the balance of capital expenditures were financed by external grants and loans - there was no national or subnational domestic public debt. There was also a steadily decreased reliance on oil and gas revenues, and a comprehensive tax reform in the 1980s that included introduction of a value added tax, the outsourcing of customs services, and substantial modification of direct taxes.

\footnotetext{
${ }^{4}$ See Rosengard 2002 for a detailed description of Indonesia’s pre-crisis macroeconomic performance.
} 
Other examples of Indonesia’s prudent fiscal policies prior to the crisis include: ${ }^{5}$

- Consistently running a budget surplus, which totaled 2.2 percent of GDP in 1995 and 1.2 percent of GDP in 1996.

- Generating revenue in FY 1996/97 $7^{6}$ equivalent to 16.0 percent of GDP.

- Relying predominantly on non-oil and gas taxes despite being a major exporter of both products, which generated 65 percent of total revenue and 74 percent of tax revenue in FY 1996/97 - most of this came from the income tax (35 percent of tax revenue) and the value added tax (26 percent of tax revenue).

- Increasing government expenditure as a share of the economy while continuing to generate a budget surplus, reaching 14.9 percent of GDP in FY 1996/97.

- Maintaining a conservative expenditure profile, with 62 percent for current expenditures (28 percent for personnel and 10 percent for materials) and 38 percent for development spending in FY 1996/97 - 14 percent of expenditures went for debt service in FY 1996/97, or approximately 2 percent of GDP.

During the decade prior to the crisis, Indonesia also implemented a very low-profile but quite significant de facto if not de jure fiscal decentralization policy: ${ }^{7}$

- Subnational (provincial and district/municipal) own source revenue rose in real per capita terms an average of more than 11 percent per year from FY 1985/86 to FY 1994/95.

- Block grants (Inpres) as a share of total central government capital grants and transfers to subnational governments was increased to and then maintained at between 20 to 24 percent for several years.

- Subnational governments were gradually given increased discretion within these block grants.

- Support was shifted from the provincial to the lower district/municipal level of local government, as the district/municipal share of all central government grants and subsidies rose from 44 percent in FY 1989/90 to 58 percent in FY 1996/97.

Similar to the situation in Thailand, there was nothing exceptional or alarming in Indonesia's fiscal policies prior to the financial crisis, and like Thailand, the crisis clearly

\footnotetext{
${ }^{5}$ The data in this section come from ARIC (2000) and the World Bank (1998), and refer to only central government revenues and expenditures.

${ }^{6}$ The pre-crisis fiscal year was 1 April to 31 March. Indonesia changed its fiscal year in 2001 to coincide with the calendar year (1 January to 31 December); most data for FY 2000 only cover nine months.

${ }^{7}$ The data in this section come from Bureau for Regional Financial Analysis (1997).
} 
was not caused by public sector extravagance. Indonesian fiscal policies were sound, resulting in a strong short- to medium-term fiscal position prior to the crisis.

The only potential significant threats to fiscal stability were long-term. The most critical of these were extremely large contingent liabilities, comprised of substantial off-budget accounts (the balance was at least $\$ 9.5$ billion 1996), considerable losses of many stateowned enterprises ( $\$ 9.4$ billion in 1996), and like Thailand, unfunded pension programs whose burden would increase dramatically with the aging of Indonesia's population (World Bank 1998). Poor tax administration, primarily lack of compliance and enforcement, also posed long-term threats to fiscal stability.

\section{Post-Crisis Fiscal Policies}

\section{Thailand}

Key determinants of Thailand's post-crisis fiscal prognosis are annual budget dynamics, long-term debt management, and exposure to contingent liabilities. Thus, each of these factors will be reviewed to assess Thailand's future fiscal strengths and vulnerabilities.

Thailand has maintained fiscal discipline regarding on-budget expenditures. It has kept its central government budget deficit below three percent of GDP every year since the crisis except when it reached 3.3 percent in 1999, and the budget deficit for 2002 was only 1.4 percent of GDP (IMF 2003a). Both the Government of Thailand and the IMF project that this deficit will continue to fall as a percentage of GDP, and that Thailand will run a surplus beginning in FY2004/05 (FPRI 2003 and IMF 2004a).

These projections also estimate that for the next five to seven years, revenue will remain at between 16.3 and 16.5 percent of GDP, and interest expenditures will stay at between 1.5 and 1.8 percent of GDP (FPRI 2003 and IMF 2004a). Other projections also indicate no substantial change in the composition of revenue or expenditures within these broad parameters, with the exception of an increased share of the budget devoted to resource transfers to local governments as part of a long-term devolution policy. ${ }^{9}$

Thailand's management of its long-term debt has also been prudent. While total public debt shot up from 14.5 percent of GDP in 1996 to 57.9 percent of GDP in 2001, this debt ratio is beginning to decline, and unless conditions and policies change dramatically, does not threaten Thailand's overall fiscal soundness. ${ }^{10}$

\footnotetext{
8 Thailand's fiscal year runs from 1 October to 30 September. Depending on the source and the application, figures are given on either a fiscal year basis or have been adjusted for international comparison to a calendar year basis, and the time period used is noted accordingly.

${ }^{9}$ Author's calculations using data provided by the Comptroller-General of Thailand and the BOT.

${ }^{10}$ The data regarding public debt come from IMF 2003a, IMF 2003b, and IMF 2004a.
} 
Total public debt has two principal components: government debt, comprising central government debt and liabilities of the Financial Institutions Development Fund (FIDF) ${ }^{11}$; and the debt of non-financial public enterprises (NFPEs).

Government debt increased more than seven-fold from its 5.2 percent debt ratio ${ }^{12}$ in 1996 to 38.8 percent in 2000 , as public expenditures were made to support financial institutions and expansionary fiscal policies were pursued to stimulate economic recovery. Interest payments rose accordingly, from 0.2 percent of GDP and 1.1 percent of budget expenditures in 1996 to 1.2 percent of GDP and 7.0 percent of budget expenditures in 2000.

However, government debt has stabilized since then. The central government debt component has grown quite slowly over the past four years, due to a combination of resumption of economic growth, moderate revenue buoyancy, a drop in short-term interest rates, a smaller than anticipated fiscal expansion in FY 2001/02, and an increase in quasi-fiscal activities, especially policy-based credit expansion by government-owned specialized financial institutions (SFIs).

There are two main risks in managing the central government debt. The first is a significant and sustained slowdown in economic growth, caused either by another externally-generated shock or failure to address the structural weaknesses that created the economic vulnerabilities of the 1997 financial crisis. This could lead to both a large revenue shortfall, as well as increased public expenditures to stimulate the economy and mitigate the economic downturn's effect on the poor.

The second significant risk in managing the central government debt is the fiscal burden of substantially increased intergovernmental transfers, estimated to increase from 1.4 percent of GDP in FY2000/01 to 3.7 percent of GDP in 2005/06, if not offset by a comparable reduction in central government expenditures. The decentralization law requires local revenues (inclusive of transfers from the central government) to reach 35 percent of central government revenues (net of VAT transfers to local governments mandated under the Decentralization Act) by 2005/06, and it is estimated that the transfer of VAT revenues to local governments will hit its legal ceiling (30 percent of gross VAT collections) this fiscal year (IMF 2004a). ${ }^{13}$

The FIDF component of government debt is now about one-third of its peak size (roughly 20 percent of GDP) as a result of fiscalization of FIDF's losses via the issuance of

\footnotetext{
${ }^{11}$ FIDF was established in 1985 as an independent body within the BOT to provide public support to the financial system. It maintains separate financial accounts and is overseen jointly by the BOT and the Ministry of Finance. In 1997, FIDF introduced a blanket guarantee covering all depositors and most creditors of local banks, finance companies, and credit fonciers. FIDF has also been responsible for bank recapitalization and other rehabilitation measures under the 1998 Financial Sector Restructuring Plan.

${ }^{12}$ The ratio of debt to nominal GDP.

${ }^{13}$ According to the IMF, "VAT revenues which are passed down to local governments consist of three parts: 10 percent of total VAT collections as the sharing part of local government; 5 percent of VAT from provinces (other than Bangkok) to Provincial Administrative Organizations; and additional VAT transfers under the Decentralization Act.” (IMF 2004a, p. 20)
} 
government bonds (IMF 2004a). FIDF's estimated total losses are B1.4 trillion (about \$32.6 billion, or 26 percent of 2002 nominal GDP), consisting of: B554 billion from assistance to depositors and creditors and liquidity support (56 closed finance companies and other financial institutions); B169 billion from recapitalization in "intervened" financial institutions; B651 billion from managing non-performing assets; B166 billion from interest and other expenses; less B139 billion in FIDF premiums and other income (TISC 2002).

Fiscalization has proceeded as follows: 1) FIDF1 - Initial issuance of B500 billion in FIDF bonds in May 1998; 2) FIDF2 - Government guarantee of B112 billion in FIDF bonds in October 2000; 3) FIDF3 - Approval in June 2002 to issue another B780 billion in bonds as needed, of which the first tranche was issued in September 2003, B305 billion in government savings bonds. The interest burden for all of these bonds will be borne by the budget, while the principal will be covered as follows: 1) FIDF1 - 90 percent of BOT profits, paid off in 30 years without privatization revenues; 2) FIDF2 and FIDF 3 - Annual net profits from BOT currency reserves, paid off in 19 years (TISC 2002 and IMF 2004a).

Fiscalization of FIDF's liabilities does not affect the overall level of government debt as defined above, but rather, simply changes its composition. Thus, the government debt ratio is still expected to decline over the next six years to about 30.3 percent in FY2009/10, except for a temporary increase in FY 2004/05 and FY 2005/06 caused by the anticipated realization of FIDP off-balance sheet liabilities. ${ }^{14}$ These projections include a planned government subsidy of approximately B55 billion (about one percent of GDP) for the construction of 600,000 low-cost housing units.

NFPE debt in FY 1995/96 was a moderate 9.3 percent of GDP, but more than doubled after the crisis to 19.2 percent of GDP by FY 2000/01 (IMF 2003b). The NFPE debt ratio is now declining, estimated to be 15.8 percent in FY 2002/03 (IMF 2004a) and 29.5 percent of total public debt as of June 2003 (FPRI 2003).

Thailand has contingent liabilities in four main categories: SFIs, NFPEs, the FIDF blanket guarantee of financial institution depositors and creditors, and unfunded pension obligations. In this discussion, a relatively broad concept of contingent liabilities is used, so that they include both explicit and implicit current central government obligations to make payments in the future if specific adverse events occur. The fiscal burden of these contingent liabilities (the expected cost to the government) is a function of the value of the liability and the probability of the contingency occurring. ${ }^{15}$

Despite the relatively high profile of SFIs and the government's recent increase in policybased lending via SFIs, the contingent liabilities of SFIs are still small. The most likely scenario estimates an SFI contingent liability of less than 0.5 percent of GDP, while

\footnotetext{
${ }^{14}$ According to the IMF, "The bulk of these obligations under yield maintenance and gain/loss sharing and liquidity support to financial institutions are to fall due in 2004/05-2005/06 for a total amount of some B550 billion.” (IMF 2004a, p. 20)

${ }^{15}$ See IMF 2001 for a more detailed discussion of contingent liabilities.
} 
under a more conservative scenario, this rises to about 3.5 percent of GDP (IMF 2004a). ${ }^{16}$

Likewise, the contingent liabilities of NFPEs are also quite low. While extremely diverse and comprising some loss-making enterprises, the NFPE sector as a whole has substantial positive net worth (16 percent of GDP at the end of FY2001/02), is generally profitable (FY2001/02 profits were about 2 percent of GDP), and is a net contributor to the budget (FY2001/02 contributions totaled 0.5 percent of GDP). Depending on what portion of NFPE debt is considered a contingent liability, the government's burden is anywhere from 4.0 percent of GDP (the debt of loss-making NFPEs) to 16.0 percent of GDP (all NFPE debt as of March 2003) - a middle ground is 13.4 percent of GDP (the government-guaranteed portion of NFPE debt) (IMF 2004a).

The largest documented government contingent liability is the blanket guarantee introduced in 1997 of all depositors and most creditors of domestic financial institutions. At the end of 2002, this guarantee covered liabilities that were slightly larger than total GDP. While it is extremely unlikely that the blanket guarantee would be realized in its entirety, it is nonetheless a potentially large cost to the government should the financial sector experience another crisis (IMF 2004a).

There is scant public information regarding unfunded government pension liabilities in Thailand. However, this is a worldwide problem, and will clearly grow in importance as Thailand's demographics continue to reflect its increasing wealth: an aging population of fewer workers (taxpayers) supporting more retirees who live longer (pensioners) due to falling birthrates and longer life expectancies (Holzmann, MacArthur, and Sin 2000; Holland 2003). Although the Government Pension Fund, established in 1997, is a fully funded defined contribution scheme, the much larger social security system is a defined benefit pay-as-you-go (PAYG) scheme, with any funding shortfalls for the payment of annuities coming directly from the government's budget. This constitutes a major contingent liability as an increasing portion of the labor force joins the PAYG pension scheme, due to a combination of gradually expanded coverage under the terms of the 1990 Social Security Act and the formal sector's growing share of Thailand's economy.

\section{Indonesia}

Like Thailand, Indonesia too has adopted prudent fiscal policies since the crisis, and has made substantial progress in managing its public debt. Also similar to Thailand, Indonesia still has significant fiscal vulnerabilities. Indonesia's annual budget performance, multi-year debt management, and exposure to contingent liabilities will each be assessed to formulate a prognosis for Indonesia's future fiscal performance.

\footnotetext{
${ }^{16}$ The IMF calculates the SFI contingent liabilities by estimating the cost of liquidating the SFIs. The IMF assumes that the cost to the government would be the additional funds needed to settle all SFI depositor and creditor claims after all capital and all proceeds from asset sales were exhausted; the value of asset sales is determined by applying different assumptions regarding loan recovery rates. The "most likely" scenario assumes that 50 percent of the loan book goes bad, and that recovery varies according to loan type; the "conservative" scenario also assumes that 50 percent of the loan book becomes NPLs, but then assumes that the recovery rate is zero (IMF 2004a, pp. 21-22).
} 
Indonesia has been quite prudent with on-budget expenditures since the crisis. It has kept its budget deficit to less than 3.0 percent of GDP every year except 2001, when the debt ratio reached a peak of 3.7 percent. The 2003 budget deficit was 1.9 percent of GDP, and the debt ratio is expected to continue to decline until Indonesia achieves a balanced budget in 2006 (Ministry of Finance, ARIC 2000, and IMF 2004b).

Total revenue (including grants), however, is expected to fall from 20.8 percent of GDP in 2001 to 17.7 percent of GDP in 2004. Even with a rather optimistic forecast of tax revenues increasing two percent of GDP (11.2 to 13.2 percent) during the same period, this is not enough to offset an expected decline in oil and gas revenues of more than four percent of GDP (7.2 to 2.9 percent).

On the expenditure side, subsidies are projected to decline, dropping four percent of GDP from 2001 to 2004 (5.3 to 1.3 percent), while interest payments are expected to decline more than three percent of GDP (6.6 to 3.3 percent) during these three years (IMF 2004b). Although transfers to the regions are expected to rise from 5.6 to 6.1 percent of GDP from 2001 to 2004, this is still well below the 7.6 percent of GDP achieved in FY1995/96, the last pre-crisis year for which complete data are available (BAKD 1997 and Ministry of Finance 2002). This is contrary to the widespread belief ${ }^{17}$ that the current decentralization program has increased the total central government-generated resources available to local governments as a share of the national economy. ${ }^{18}$

While Indonesia's public sector gross debt ${ }^{19}$ rose dramatically from its pre-crisis level of 24.5 percent of GDP in FY1996/97 to a post-crisis high of 104.1 percent in 2000, the debt ratio has declined steadily since then to 68.2 percent of GDP in 2003. Roughly twothirds of the 2003 public sector gross debt is particularly susceptible to external vulnerabilities, comprising external debt from official creditors (43.6 percent) and private creditors ( 0.3 percent), as well as domestic debt linked to short-term interest rates or inflation (18.7 percent) or to foreign currency (1.0 percent) (IMF 2004b).

This improvement is especially encouraging given the issuance of approximately Rp 740 trillion in government bonds ( $\$ 87$ billion at the current exchange rate), equal to twothirds of 1999 GDP (when most of the bonds were issued). These bonds were issued to cover a number of liabilities incurred during the financial crisis: compensation to Bank Indonesia for liquidity and solvency support to struggling banks; compensation to banks that assumed liabilities of banks closed by the government; and recapitalization of undercapitalized banks that remained open (Rosengard 2002).

\footnotetext{
${ }^{17}$ For example, see World Bank 2003a or IMF 2002.

${ }^{18}$ The comparison is difficult to make because of a total reclassification of government transfers. All transfers under the old system (current and development expenditures) are compared with all transfers under the new system (equalization funds, special autonomy funds, and equalizing funds). Specifically, old system transfers include SDOs (primarily salary subsidies), regional DIPs (centrally funded investments in the regions), Inpres (block grants), and revenue sharing; new system transfers include general allocation funds, special allocation funds, shared revenues, special autonomy grants, and balancing funds.

${ }^{19}$ Public sector gross debt consists of medium- and long-term debt, excluding outstanding IMF purchases.
} 
Total financing requirements in 2004 are estimated to be Rp 94.3 trillion ( $\$ 11.1$ billion), consisting of the projected budget deficit (Rp 24.9 trillion), domestic debt amortization (Rp 18.9 trillion), domestic bond buybacks (Rp 5.6 trillion), and external debt amortization (Rp 44.9 trillion). This amounts to 4.6 percent of GDP, and is equal to onequarter of the 2004 budget. The Government of Indonesia plans to meet these financing requirements from the following sources: government deposits in domestic banks (Rp 26.3 trillion), privatization (Rp 5.0 trillion), IBRA (Indonesian Bank Restructuring Agency ${ }^{20}$ asset sales (Rp 5.0 trillion), issuance of domestic bonds (Rp 28.0 trillion), issuance of international bonds ( $\mathrm{Rp} 3.5$ trillion), and official sources (Rp 26.5 trillion) (Citigroup 2003 and World Bank 2003b).

Indonesia has the same two risks faced by Thailand in managing its central government debt: a large revenue shortfall coupled with increased public expenditures should the country suffer another significant and sustained slowdown in economic growth; and the fiscal burden of substantially increased intergovernmental transfers, now comprising 90 percent of total local government revenues (World Bank 2003a), if not offset by a comparable reduction in central government expenditures. ${ }^{21}$

Indonesia's four largest contingent liabilities are: the cost of liquidating governmentowned banks, government guarantees of NFPE debt, the government's January 1998 blanket guarantee of bank obligations to depositors and creditors, and unfunded pension obligations. As in the earlier analysis of Thailand's contingent liabilities, this discussion utilizes a relatively broad concept of contingent liabilities so that they include both explicit and implicit current central government obligations to make payments in the future if specific adverse events occur.

Prior to the crisis, there were seven state-owned banks with 86,700 employees and assets comprising 30.4 percent of GDP. However, government interventions to stabilize the banking system also resulted in a massive nationalization of the financial sector: although only four state-owned banks remained after four of the original seven state banks were merged, the government also became the majority owner of eleven previously private banks. ${ }^{22}$ As the government is now in the process of selling its share in the formerly private banks, as well as reducing its stake in state banks, the magnitude of Indonesia's contingent liabilities from liquidation of banks that it owns is unclear - the government has yet to calculate the additional funds it would need to settle all depositor and creditor claims after applying all capital and all proceeds from asset sales. Thus, we shall treat this as part of the blanket guarantee contingent liability discussed below.

\footnotetext{
${ }^{20}$ According to its website (http://www.bppn.go.id/about ibra.asp), IBRA is "a special agency established by the government in early 1998 to help rehabilitate the national economy through the Government Guarantee Scheme, the Restructuring Program, as well as Corporate Loan Restructuring.” IBRA is scheduled to close in February 2004.

${ }^{21}$ According to Law 25 of 1999 and subsequent implementation regulations, DAU (Dana Alokasi Umum, or General Allocation Fund) grants must equal a minimum of 25 percent of actual central government revenues after tax and revenue sharing (World Bank 2003a).

${ }^{22}$ These were classified as BTO (Bank Takeover) and Recap (Recapitalized) Banks; there were four BTO Banks and 7 Recap Banks.
} 
Public information on the assets, liabilities, and performance of NFPEs is dated and incomplete. The transparency of this sector has not improved significantly since the crisis, and disclosure requirements lag far behind data now published by Indonesia's financial sector. Nonetheless, available data indicate that NFPE external borrowing does not create a substantial contingent liability.

Prior to the crisis, NFPEs played a significant role in the Indonesian economy: in 1996, they employed 837,000 persons, and had assets and equity totaling 33.1 percent and 16.7 percent of GDP, respectively. NFPEs in the regulated sector, comprised primarily of public utilities such as Pertamina (oil and gas), PLN (electricity), and PT Telkom (telecommunications) accounted for 65 percent of assets and revenues and 71 percent of equity. The state-owned plantations (PTPNs) were the dominant NFPE employer, accounting for 38 percent of the total NFPE work force (World Bank 1998).

A review early in the crisis concluded that, as a sector, the NFPEs have: been a net drain on public resources when capital transfers are taken into account; not earned the cost of capital invested in them; and included many that were illiquid and/or insolvent. This review also identified several large NFPEs with considerable external debts that they would not be able to service, especially given that these were foreign exchange denominated obligations while the NFPEs received rupiah revenues at controlled prices (World Bank 1998). Nonetheless, as of 1999, all NFPE debt comprised only 6.7 percent of total public sector debt, and these figures are already included in the previous debt management discussion (IMF 2000). Thus, while the NFPEs might impose significant fiscal costs due to financial inefficiencies and economic distortions, they do not create sizable government contingent liabilities.

The largest documented government contingent liability is the blanket guarantee provided by Presidential Decree No. 26 of January 1998 covering both domestic and foreign currency claims of all bank depositors and creditors except the holders of subordinated debt (Rosengard 2002). At the end of 2002, this guarantee covered liabilities that were approximately half of total GDP. ${ }^{23}$ While normally only a relatively small portion of this blanket guarantee would ever be utilized, it is still a potentially large cost to the government should the financial sector experience another crisis, especially since the guarantee fund administered by IBRA had a balance that covered less than one percent of the guaranteed liabilities of banks in 2001 (IMF 2003a and IBRA web site).

There are three main retirement funds in Indonesia: the ASABRI pension fund for police and defense personnel (military and civilian); the TASPEN pension fund for civil servants; and the JAMSOSTEK provident fund for private sector and state-owned enterprise employees. Another 300 private sector employers and state-owned enterprises had their own retirement funds. The combined assets of these retirement funds totaled Rp 36 trillion at the end of 2002, roughly 2.2 percent of GDP (World Bank 2003b).

\footnotetext{
${ }^{23}$ The number varies slightly depending on one's interpretation of effective coverage. A relatively inclusive interpretation would include domestic money bank: demand, time, savings, and foreign currency deposits; money market instruments; restricted deposits; and foreign liabilities. In December 2002 this totaled Rp 860.8 billion, or 53.5\% of nominal GDP (IMF 2003a and IMF 2004b).
} 
Most of these retirement funds, especially the three large government-linked ones, are characterized by poor governance, chronic mismanagement, sub-optimal return on investments, lack of transparency and disclosure, and inadequate regulation and supervision. ASABRI and TASPEN are nominally under the Ministry of Defense and Ministry of Finance respectively, but are effectively not supervised and often subject to political and personal influences. Both pension funds are substantially underfunded they cannot even meet their current obligations without general budgetary support, much less finance the payment of future pension benefits (World Bank 2003b). ${ }^{24}$ This problem is only expected to grow worse as the ratio of pensioners to workers increases in Indonesia due to an aging population and growing coverage of retirement schemes.

\section{Conclusion}

So will bank bailouts bust budgets in Thailand and Indonesia? Will fiscalization of the East Asian financial crisis create an East Asian public finance crisis? To use a series of Indonesian acronyms, will Krismon (Monetary Crisis), which evolved into Kristal (Total Crisis), transmute into Kriskal (Fiscal Crisis)?

Not this time. If Thailand or Indonesia now experiences a fiscal crisis, it will be the result of other factors. Both countries have addressed the short-term triggers of the financial crisis admirably, and continue to monitor vigilantly their external vulnerabilities. Macroeconomic stability and real economic growth have resumed, reserves have been rebuilt, public finance policies have been prudent, debt burdens are manageable, and contingent liabilities modest.

The two most significant short- to medium-term threats to fiscal health for Thailand and Indonesia are: 1) a significant and sustained decline in economic growth, caused either by an external shock or internal instability (the latter more likely in Indonesia than Thailand), which would simultaneously decrease revenues and increase expenditures; and 2) the implementation of ambitious fiscal decentralization programs, whose formuladriven legal mandates will, without a dramatic increase in public sector borrowing, decrease central government resources for investments in public infrastructure and equalization expenditures between regions just when they are needed most to boost economic growth and preserve social and political stability.

The two most significant medium- to long-term threats to fiscal soundness for Thailand and Indonesia are: 1) structural vulnerabilities due to incomplete or insufficient financial sector reform that could require another substantial bank bailout program; and 2) payout of contingent liabilities, particularly for bank guarantees and pension benefits. The more imminent threat is stalled financial sector reform, which does indeed link a potential future fiscal crisis to the past financial crisis, albeit in a rather unexpected way.

\footnotetext{
${ }^{24}$ According to the Asian Development Bank, in 2000, ASABRI was in cash flow deficit (excess of payouts over contributions) of Rp 30 billion and TASPEN was in cash flow deficit of Rp 13.5 trillion (World Bank 2003b).
} 
While banks are now liquid and solvent, lack of domestic financial intermediation can be an increasingly critical constraint to economic growth. Reduced lending for productive investment is due partly to weak effective demand, the risk aversion of newly recapitalized banks, and the crowding out of private sector credit by public sector debt. It is also the result of significant underlying problems that have not yet been adequately addressed: concentration of bank ownership, barriers to entry, lack of competition, low efficiency, limited market coverage, and the debt overhang of asset management institutions.

The challenge is to persevere with financial sector reform. This entails continued bank restructuring, improved bank governance, enhanced capital market supervision, liquidation of asset management institutions, accelerated re-privatization, and the facilitation of entry into and competition within the financial sector. If successfully executed, these measures should enhance the soundness of financial institutions while at the same time increase access to essential financial services. Fiscalization of the 1997 East Asian financial crisis will not precipitate a fiscal crisis, but failure to complete fundamental financial sector reforms can result in fiscal calamity. 


\section{References}

Asia Recovery Information Center (ARIC) (2000). Asia Recovery Report (ARR). Manila: Asian Development Bank, March.

Bureau for Regional Financial Analysis (BAKD), Agency for Financial and Monetary Analysis, Ministry of Finance, Republic of Indonesia, in cooperation with Bappenas, the Ministries of Home Affairs and Public Works, and the Municipal Finance Project (1997). Monitoring Indicators of Repelita VI Urban Policy Action Plan Implementation Results, Main Text and Annexes. Jakarta: Municipal Finance Project, April.

Citigroup (2003). Beyond 2004: More on Post IMF Policy and Financing Outlook. Update Note, October.

Fiscal Policy Research Institute, Ministry of Finance, Royal Thai Government (2003). Thailand's Economic Outlook: Towards Sustainable Balanced Growth, presentation at the Conference on Institutional Development in Finance in East Asia, Bangkok, 31 October - 1 November 2003, September.

Holland, Tom (2003). “Asia’s Huge Unfunded Gap,” Far Eastern Economic Review, pp. 42-4, January 23.

Holzmann, Robert, MacArthur, Ian W., and Sin, Yvonne (2000). Pension Systems in East Asia and the Pacific: Challenges and Opportunities, Social Protection Unite. Washington, D.C.: World Bank.

International Monetary Fund (2000). Indonesia: Statistical Appendix, IMF Country Report No. 00/133. Washington, D.C.: International Monetary Fund, October.

International Monetary Fund, Fiscal Affairs Department (2001). Manual on Fiscal Transparency. Washington, D.C.: IMF.

International Monetary Fund, Fiscal Affairs Department (2002). Intergovernmental Grants Systems and Management: Applications of a General Framework to Indonesia, IMF Working Paper WP/02/128. Washington, D.C.: International Monetary Fund, August.

International Monetary Fund (2003a). International Financial Statistics. Washington, D.C.: International Monetary Fund, December.

International Monetary Fund (2003b). Thailand: Statistical Appendix, IMF Country Report No. 03/388. Washington, D.C.: International Monetary Fund, December.

International Monetary Fund (2004a). Thailand: Selected Issues, IMF Country Report No. 04/01. Washington, D.C.: International Monetary Fund, January. 
International Monetary Fund (2004b). Indonesia: Eleventh Review Under the Extended Arrangement, IMF Report No. 04/18. Washington, D.C.: International Monetary Fund, January.

Ministry of Finance, Republic of Indonesia (2002). Nota Keuangan dan UndangUndang Republic Indonesia Nomor 29 Tahun 2002 Tentang Anggaran Pendapatan dan Belanja Negara Tahun Anggaran 2003 [Finance Note and Republic of Indonesia Law Number 29 of Year 2002 Regarding the Fiscal Year 2003 National Budget]. Jakarta: Ministry of Finance.

Rosengard, Jay K. (2002). Reforming the Financial Sectors of Thailand and Indonesia: Myth Perceptions of Ramakien and Ramayana Capitalists, Paper Presented at the Conference on Financial Sector Reform Across Asia: Facts, Analyses, Solutions, Harvard University, Cambridge, Massachusetts, 10-11 December 2002.

Thailand Investor Service Center (TISC) (2002). Thailand Outlook.com: The Official Gateway and Guide to Thailand for Investors. Bangkok: TISC.

Warr, Peter G (1999). What Happened to Thailand?, Working Paper in Trade and Development No. 99/3. Canberra: Division of Economics, Research School of Pacific and Asian Studies, Asia Pacific School of Economics and Management, The Australian National University, June 1999.

World Bank (1998). Indonesia Public Expenditure Review: The Budget, Off-Budget Items, State-Owned Enterprises, Report No. 18691-IND. Washington, D.C.: World Bank, October.

World Bank (2003a). Decentralizing Indonesia: A Regional Public Expenditure Review Overview Report, Report No. 26191-IND. Washington, D.C.: World Bank, June.

World Bank (2003b). CGI Brief: Beyond Macroeconomic Stability, Report No. 27374IND. Washington, D.C.: World Bank, December. 